Отже, потреба у висококваліфікованих фахівцях інженерної галузі, що володіють на належному рівні проектно-конструкторською компетентністю, залишається питанням, яке потребує подальших досліджень. Водночас студент має засвоїти знання й оволодіти графічними вміннями й навичками, які дозволять йому успішно здійснювати проектно-конструкторську діяльність; опанувати необхідну сукупність компетентностей для цієї діяльності у процесі графічної підготовки.

\title{
Література
}

1. Доклад международной комиссии по образованию, представленный ЮНЕСКО «Образование: сокрытое сокровище». - М. : ЮНЕСКО, 1996. - 31 с. 2. Болотов В. А. Компетентностная модель: от идеи к образовательной программе / В. А. Болотов, В. В. Сериков // Педагогика. - 2003. -№ 10. - С. 8-14. 3. Закон України «Про вищу освіту» № 2984-III від 17 січня 2002 р. // Вісник Верховної Ради України. - 2002. - № 20. - С. 134. 4. Зимняя И. Ключевые компетенции - новая парадигма результата образования / И. Зимняя// Высшее образование сегодня. 2003. - № 5. - С. 34-42. 5. Иванова Т. В. Компетентностный подход к разработке стандартов для 11-летней школы: анализ, проблемы, выводы / Т. В. Иванова // Стандарты и мониторинг в образовании. - 2004. - №1. - С. 16-20. 6. Муравлев И. О. Формирование специалистов в области техники и технологии для инновационной инженерной деятельности [Электронный ресурс]/ И. О. Муравлев, О. В. Блейхер. - Режим доступу: http://aeer.cctpu.edu.ru /winn/magazine/m2/st25.pdf. 7. Указ Президента України «Про Національну стратегію розвитку освіти в Україні на період до 2021 року» від 25 червня 2013 року №344/2013/ [Електронний ресурс]. - Режим доступу: http://zakon2.rada.gov.ua/laws/show/344/2013. 8. Шишов С. Е. Компетентностный подход к образованию как необходимость / С. Е. Шишов, И. Г. Агапов // Мир образования - образование в мире. - 2001. - № 4. - С. 8-19.

УДК $378.011 .3: 338.48-051$

Галина Щука

\section{ОРГАНІЗАЦІЯ НАВЧАЛЬНИХ ТА ВИРОБНИЧИХ ПРАКТИК У ПРОЦЕСІ ПІДГОТОВКИ ФАХІВЦІВ СФЕРИ ТУРИЗМУ}

Щука Г. П. Організація навчальних та виробничих практик у процесі підготовки фахівців сфери туризму.

У статті аналізується рівень організації навчальних і виробничих практик у процесі підготовки вітчизняних бакалаврів 3 туризму. Автором оцінюється нормативна тривалість практик та встановлюються можливості іiї подовження; розглядається дієва технологія проектування процесу практичної підготовки та визначаються іiі недоліки; уточнюється принцип формування змісту практик та простежується зв'язок теоретичної та практичної підготовки.

Ключові слова: туризм, практика, галузевий стандарт вищої освіти, напрям підготовки «Туризм», бакалавр з туризму.

Щука Г. П. Организация учебных и производственных практик в процессе подготовки специалистов сферы туризма.

В статье анализируется уровень организации учебных и производственных практик в процессе подготовки отечественных бакалавров туризма. Автором оценивается нормативная продолжительность практик и устанавливаются возможности еe продления; рассматривается действующая технология 
проектирования процесса практической подготовки и определяются ее недостатки; уточняется принцип формирования содержания практик и прослеживается связь между теоретической и практической подготовками.

Ключевые слова: туризм, практика, отраслевой стандарт высшего образования, направление подготовки «Туризм», бакалавр туризма.

Shchuka G. P. Organization of educational and industrial practice in the process of training specialists in the sphere of tourism.

The article analyzes the level of organization of educational and industrial practice in the process of training of domestic bachelors tourism. The author assesses the normative duration of practices and installed the possibility of its prolongation; discusses the current technology designing of the process of practical training and are determined by its disadvantages; clarifies the principle of formation of the contents of practices and traced the existing communications theoretical and practical training.

Key words: tourism, practice, branch standard of higher education, training direction «Tourism», bachelor of tourism.

Надання туристичних послуг як вид практичної діяльності характеризується низкою специфічних особливостей, які відрізняють його від інших видів сучасних професій. Одна 3 них - це специфіка професійної взаємодії та інтеракції між фахівцем і клієнтом. На відміну від рольових суб'єкт-об'єктних взаємозв'язків, характерних для більшості професій, у сфері туризму домінують суб'єкт-суб'єкті 3 певним рівнем довіри, у яких турист зберігає за собою право приймати рішення.

Працівникам туристичних підприємств доводиться працювати 3 людьми, які кардинально різняться за психотипом, рівнем достатку, віком, інтересами, станом здоров'я тощо. Тому від фахівця сфери туризму, як з боку працедавців, так із боку клієнтів, вимагається високий рівень сформованості комунікативних, пізнавальних, організаторських, рефлексивних, креативних, емпатійних умінь, навичок саморегуляції тощо. А це, у свою чергу, передбачає грунтовну теоретичну підготовку, закріплену у практичній діяльності та реальній взаємодії $з$ туристами.

Основою формування професійних компетентностей майбутнього фахівця сфери туризму $є$ організація практико-орієнтованої підготовки, яка дозволяє оптимально поєднувати теоретичне та практичне навчання. У провідних туристських країнах практичні заняття організовуються на базі підприємств індустрії туризму та проводяться за однією з трьох схем:

- «дуальна» модель - практика триває протягом усього навчального року паралельно 3 навчальними заняттями. Ця модель організації практик найбільш поширена в Німеччині, де навчальні заклади належать підприємствам галузі, а навчальні плани розробляються виробничими асоціаціями;

- «сандвіч» - англійська модель, за якою практика здійснюються у середині курсу;

- шведська модель - передбачає щотижневе «чергування» теоретичної і практичної підготовок, що дозволяє уникнути абстрактного викладання під час тривалого навчання. Але жодна з цих моделей не знайшла практичного втілення у процесі підготовки фахівців галузі туризму в Україні.

Варто зазначити, що до аналізу проблем організації і проведення практик вітчизняні й зарубіжні науковці зверталися неодноразово. Здійснено аналіз окреслених питань у роботах Ю. Апакової, А. Ареф’єва, В. Васильєва, Р. Давидова, Л. Польової, I. Попова, Л. Скоробогатової, Л. Телевної, Н. Хмілярчук, 
В. Федорченка, Г. Цехмістрової, Л. Чорної та ін. Проте всі вони доходять висновку про надзвичайну ефективність такої організації практик i неможливість використання закордонного досвіду у вітчизняній системі професійної туристичної освіти. Водночас нами не виявлено робіт, у яких би осмислювався і грунтовно аналізувався стан організації і проведення практик у бакалаврів із туризму.

Тому мета статmі - проаналізувати організацію і проведення практик у процесі підготовки бакалаврів із туризму в Україні.

Організація практик вітчизняних бакалаврів з туризму здійснюється відповідно до Положення про проведення практик студентів вищих навчальних закладів України (далі Положення) [4] та Галузевого стандарту вищої освіти [1] (далі Стандарт). Мінімальний навчальний час, який відводиться Стандартом на проведення практик складає 9,0 кредитів СКТС (це 6 тижнів, 3,75 \% від загального навчального часу) [1, c. 11]. Для порівняння відзначимо, що під час підготовки майбутніх бакалаврів 3 туризму на проведення практик російськими стандартами виділяється не менше 12 кредитів СКТС (8 тижнів), білоруськими та польськими 15 тижнів, при цьому польські бакалаври навчаються лише три роки. Отже, порівняно 3 найближчими сусідами, ми маємо найменший обсяг практичної підготовки, щоправда, ВНЗ мають можливість його збільшити за рахунок годин навчального часу варіативної частини.

Наприклад, у Луганському національному університеті імені Тараса Шевченка практика в навчальних планах підготовки бакалавра складає 30 тижнів, в Інституті туризму Прикарпатського національного університету імені Василя Стефаника - 18; Донецькому національному університеті економіки і торгівлі імені Михайла Туган Барановського - 12; Сумському державному педагогічному університеті ім. А. С. Макаренка - 13 тижнів. Як стверджує ректор Сочинського державного університету туризму та курортної справи Г. Яковенко, найбільший ефект навчання спеціалістів індустрії туризму досягається в тому випадку, коли на практики відводиться не менше 24 тижнів [6, с. 65].

Незважаючи на те, що згідно з Положенням такі питання як перелік видів практик, їх форми, тривалість і терміни проведення, зміст і послідовність визначається навчальними закладами [4], у Стандарті наголошується на тому, що нормативними видами практик для ОКР «бакалавр» напряму підготовки «Туризм» $\epsilon$ навчальна практика «Вступ до фаху», виробнича та переддипломна практики (остання - за умови виконання дипломного проекту), а невід'ємним складником нормативної частини ОПП $є$ типові програми практик, затверджені Науковометодичною комісією зі сфери обслуговування [1, с. 11; 13].

Види практик, як вони визначені в навчальних планах підготовки бакалаврів, уражають своїм різноманіттям: навчальна, туристична, технолого-організаційна, організаційно-технологічна, комп'ютерна, зимова, літня, комплексна за фахом, міжнародна, виробнича, туристсько-краєзнавча тощо. Які саме завдання виконує студент під час проходження такої практики, сказати досить складно.

У процесі підготовки фахівців інших галузей господарства практики проводяться у своїй логічній послідовності- ознайомлювальна, навчальна, виробнича, переддипломна. Тобто у процесі проходження практик студент спочатку ознайомлюється зі своєю майбутньою професійною діяльністю, поступово заглиблюється у виробничий процес: спочатку як активний спостерігач, а потім виконавець i, нарешті, аналізує, осмислює окремі аспекти майбутньої професії на науковому рівні. 
У сфері туризму, на думку вітчизняних туризмологів (В. Федорченко, Н. Фоменко, Г. Цехмістрова та ін.), оптимальним варіантом є створення єдиної наскрізної програми практик, заснованої на моделі вертикальної організаційної структури, за якої всі працівники групуються за організаційно-кваліфікаційними рівнями (ОКР).

В. Федорченко в дисертаційній праці подає такі ОКР підготовки фахівців для сфери туризму: професійний рівень (молодший працівник) - секретар-референт, груповод, агент з туризму; технологічний рівень (молодший спеціаліст) - турагент, інструктор; організаторський рівень (бакалавр) - туроператор [5, с. 339]. Звідси, схема поступового опанування професіями у сфері туризму матиме такий вигляд: агент 3 туризму - турагент - туроператор. Щоправда, нам складно вказати на різницю між посадами агента з туризму і турагента.

Державний класифікатор професій, після неодноразових доповнень, визначив такі професії сфери туризму: професіонали в галузі туризму (наукові співробітники, туризмознавці); менеджери (управителі) туристичних агентств та бюро подорожей; консультанти 3 подорожей та організатори подорожей (екскурсовод, інструктор оздоровчо-спортивного туризму (за видами туризму); організатор подорожей (екскурсій); організатор туристичної і готельної діяльності; фахівець із розвитку сільського туризму; фахівець 3 туристичного обслуговування; фахівець із туристичної безпеки; агенти 3 туризму (агент 3 організації туризму, конторський (офісний) службовець (подорожі)); супроводжувачі в подорожах (груповод) [2].

Ураховуючи, що посада професіонала в галузі туризму вимагає повної вищої освіти, всі інші професії можна розмістити у вигляді ієрархічного ланцюга: супроводжувачі в подорожах - агенти 3 туризму - консультанти 3 подорожей та організатори подорожей - менеджери (управителі) туристичних агентств та бюро подорожей. Тоді ми отримуємо мінімум чотири практики: дві навчальні та дві виробничі. Але ж, з іншого боку, лише підготовка менеджера має передбачати проходження ознайомлювальної, навчальної, виробничої практик.

Окрім того, поза цією схемою практичної підготовки бакалаврів 3 туризму залишається їх підготовка до екскурсійної, анімаційної діяльності, роботи в секторах зеленого та спортивного туризму тощо. Випускники отримують кваліфікацію екскурсовода, отже, ця практика повинна також стати обов'язковою. Залишається проблемною підготовка інструкторів 3 туризму. Грунтовне дослідження А. Коноха свідчить, що їхня практична підготовка має відбуватися тільки в умовах туристського походу 3 отриманням відповідних кваліфікацій: 1 курс - кваліфікація «учасник»; 2 курс - «організатор спортивно-оздоровчого туризму»; 3 курс - участь у турпоході 2-3 категорії складності; 4 курс - кваліфікація «інструктор спортивно-оздоровчого туризму» [3, с. 61].

Отже, побудувати процес практичної підготовки бакалавра з туризму на основі моделі вертикальної організаційної структури практично неможливо, оскільки туристична діяльність надто різнопланова. Ми визначаємо доцільність виокремлення у напрямі «Туризм» ще двох спеціалізацій: підготовка інструкторів зі спортивно-оздоровчого туризму та підготовка екскурсоводів. Щодо підготовки фахівців з розвитку сільського туризму, то наявність такої професії у Класифікаторі викликає у нас серйозні сумніви.

Ще більша проблема виникає під час визначення завдань практики. Відсутність професійно-кваліфікаційних моделей посад туристичних підприємств у «Кваліфікаційних вимогах» ускладнює визначення змісту практик, проте НМК зі сфери обслуговування розробила на допомогу викладачам типові програми практик. 
Аналіз цих програм показав, що вони містять низку неточностей і помилок: так, визначається, що навчальна практика «Вступ до фаху» проводиться впродовж першого тижня на першому курсі навчання під час підготовки туризмологів та екскурсологів, хоча в Стандарті йдеться про підготовку бакалавра з туризму, фахівця $з$ туристичного обслуговування [1, с. 6], а туризмологи та екскурсологи це, відповідно до Класифікатора, наукові співробітники (туризмологія, екскурсознавство) з дипломом про повну вищу освіту [2].

Засвідчено значну невідповідність між завданнями практики та її тематичною структурою: всі завдання практики реалізовуються у процесі вивчення чотирьох із семи вказаних тем. При цьому назви тем занять не завжди відповідають їх змісту: наприклад, тема 1 «Галузевий стандарт вищої освіти в Україні. Організація навчального i виховного процесу у ВНЗ і на факультеті» не містить жодного речення про галузевий стандарт. Значна частина інформації, яка пропонується для ознайомлення під час практики, вивчається першокурсниками в нормативному курсі «Пропедевтика». Рекомендація проводити навчальну практику у формі диспутів також видається нам нелогічною, оскільки студенти першого курсу ще не мають відповідних теоретичних знань. Запропоновані для опрацювання матеріали зі списку основної літератури є морально застарілими, оскільки були видані в 2004 2005 рр., задовго до введення чинного Стандарту.

Не менше запитань виникає і під час аналізу програми комплексної практики, яку рекомендують проводити у три етапи: у 4, 6 та 7 семестрах. Так, другокурсники у межах практики за 2 тижні повинні ознайомитися 3 системою та принципами роботи турпідприємства; навчитися розробляти тури; готувати інформаційні матеріали, такі, як портфель екскурсовода тощо; вивчити пошукові системи й опанувати їх використання у виробничому процесі; навчитися встановлювати контакт $з$ клієнтом, регулювати взаємовідносини, знімати свою емоційну напругу, тривогу тощо. Цілком очевидно, що виконати всі ці завдання за такий короткий термін практично неможливо.

Завдання практики були визначені відповідно до нормативної частини ОПП, оскільки ОКХ бакалавра з туризму на той час розроблено не було. Тому студентів напряму підготовки «Туризм» зобов'язали на практиці опанувати технологію й організацію надання послуг розміщення та харчування, хоча це зовсім інший напрям підготовки. Не врахували розробники програми і того факту, що плановоекономічні показники діяльності туристичних підприємств є документацією для службового використання, тому в більшості випадків недоступною для студентів. 3 цієї причини більшість звітів 3 практики є формальними. Не менше запитань виникає і в процесі оцінювання тих фахових умінь і навичок, які студенти мали здобути на практиці.

Отже, у результаті проведеного аналізу ми дійшли висновку, що на окресленому етапі рівень організації навчальних і виробничих практик у процесі підготовки фахівців сфери туризму незадовільний. Терміни проведення практики замалі. Немає чіткого визначення сутності та структури туристичної діяльності, тому не зрозуміло, до якої саме роботи у сфері туризму повинен готуватися бакалавр з туризму. Чинна технологія проектування процесу практичної підготовки бакалавра з туризму на основі моделі вертикальної організаційної структури не передбачає підготовки майбутнього фахівця до анімаційної, екскурсійної діяльності, роботи у сфері спортивно-оздоровчого туризму тощо. Зміст практики визначається за знаннєвим принципом; професійні компетентності, яких має набути 
студент за період проходження практики, не визначені. Рекомендовані програми практик містять низку помилок та неточностей.

Ми практично не торкнулися не менш важливих і складних проблем, які пов'язані з визначенням баз практики, організацією практик за кордоном, за місцем проживання тощо. Нині порушені проблеми розв'язуються в індивідуальному порядку на особистих контактах керівників навчальних закладів та викладачів випускових кафедр. Назріла необхідність процес організації практик бакалаврів 3 туризму здійснювати на науковій основі. У цьому вбачаємо перспективу подальших досліджень.

\section{Література}

1. ГСВО МОН України 6.140103-2010. Галузевий стандарт вищої освіти України. Освітньо-професійна програма підготовки бакалавра напряму підготовки 6.140103 «Туризм» галузі знань 1401 «Сфера обслуговування»/ М-во освіти та науки України. - Вид. офіц. - [Чинний від 2010-11-08]. - К. : ЦІІНМВ КНТЕУ, 2010. - 14 с. 2. ДК 003:2010. Класифікатор професій. Національний класифікатор України [Електронний ресурс] :- [Чинний від 2010-11-01].- Режим доступу : http://www.kadrovik01.com.ua/ dk_01_11_2010 .html]. 3. Конох А. Професійна підготовка фахівців спортивно-оздоровчого туризму в університеті / Анатолій Конох // Гуманітарний вісник Державного вищого навчального закладу «ПереяславХмельницький державний педагогічний університет імені Григорія Сковороди» : науково-теоретичний збірник. - Переяслав-Хмельницький : ПП «СКД», 2009.C. 59-61. 4. Положення про проведення практик студентів вищих навчальних закладів України [Електронний ресурс] : Наказ Міністерства освіти України від 8 квітня 1993 р. № 93 / Кабінет Міністрів України. - [Зі змінами від 20.12.94 № 351]. - Режим доступу : http://mgu.com.ua/. - Заголовок 3 екрану. 5. Федорченко В. К. Теоретичні та методичні засади підготовки фахівців для сфери туризму: дис. ... доктора пед. наук: 13.00.04 / Федорченко Володимир Кирилович. - К., 2005. - 872 с. 6. Яковенко Г. Наша миссия - подготовка профессионалов туризма/ Г.Яковенко, Г. Романова // Высшее образование в России. - 2005. - № 10. - С. 62-68. 